\title{
Loci that determine long-term resistance to blast of Russian rice varieties
}

\author{
Julia Goncharova ${ }^{1,3, *}$, Olesya Bragin ${ }^{1}$, Sergey Goncharov ${ }^{2}$, and Evgeny Kharitonov ${ }^{1,2}$ \\ 1 Federal State Budget Scientific Institution "Federal Scientific Center for Rice", Russia, Krasnodar, \\ Belozerny, 3350921 \\ 2 Kuban State Agrarian University \\ 3 OOO "Aratay", Member of the Skolkovo Innovation Center, Moscow
}

\begin{abstract}
In all rice-growing countries, including Russia, among the economically important, dangerous and harmful diseases of rice, the main role is played blast (pathogen Pyricularia oryzae Cavara). The problem of resistance of rice plants to disease is one of the main problems in modern breeding in most countries. The most effective way to protect rice from blast is using resistant varieties created with marker assistant selection (MAS). The article presents data on chromosomal regions that provide long-term resistance of varieties to pathogen in Russia. The groups of stable and unstable samples significantly differed in the presence of polymorphic loci on the fifth, sixth, eighth, ninth and second chromosomes, which reduces the complexity of evaluating selection material due to the primary screening of gene plasms by variability of resistance loci in the identified chromosomal regions.
\end{abstract}

To date, more than 100 genes that determine resistance to blast $(\mathrm{Pi})$ in rice have been localized, but so far the data on the effectiveness of the isolated loci in the formation of the trait are contradictory [1-3]. Complicating the task is the absence of a sufficient number of differentiating varieties of the japonica subspecies [4-6]. It was previously established that even 5-7 pathogen resistance genes do not guarantee adaptability to biotic stress [7-9]. Difficulties are also created by the rapid process of mutating a pathogen and changing the racial composition of its populations, which has been significantly accelerated in recent years due to the use of new fungicides [10-12]. Our task was to isolate chromosomal regions that provide long-term resistance of varieties to pathogen in Russia.

To solve this problem, long-term data (2010-2015) on the resistance to blast of 26 domestic varieties were used. Varieties were divided into groups with different resistance to stress (Table 1).

Rice varieties were labeled using sixty molecular SSR markers, both neutral and locusrelated to adaptiviity. Analysis of variance allowed us to establish a relationship between pathogen resistance and variety variability for individual SSR markers. Since the gene plasma in the study is genetically heterogeneous, loci with the most significant contribution

\footnotetext{
* Corresponding author: yuliya goncharova20@mail.ru
} 
to phenotype could be identified in the study. The influence of variety genotype on the manifestation of the trait was not taken into account. But, even with such assumptions, we identified three chromosomal regions that reliably (at a significance level of 0.05 ) contribute to the formation of trait in domestic varieties on fifth, sixth, and eighth chromosomes.

Table 1. Resistance to blast of Russian rice varieties, \% of damage

\begin{tabular}{|c|c|c|c|c|c|c|c|c|}
\hline \multirow[b]{2}{*}{ Variety } & \multicolumn{6}{|c|}{ Year } & \multirow{2}{*}{$\begin{array}{c}\text { Average } \\
\text { value, } \\
\text { RBI, } \%\end{array}$} & \multirow{2}{*}{$\begin{array}{c}\text { Resistance } \\
\text { group }\end{array}$} \\
\hline & 2010 & 2011 & 2012 & 2013 & 2014 & 2015 & & \\
\hline Snejinka & 5.6 & 22.8 & 10.2 & 6.5 & 5.5 & 7.3 & 9.6 & 1 \\
\hline Sprint & 26.7 & 20.0 & - & - & - & - & 23.3 & 1 \\
\hline Yujniy & 17.2 & 34.4 & 15.6 & 45.6 & 15.5 & - & 25.6 & 1 \\
\hline Viola & 36.7 & 25.6 & - & - & - & - & 31.1 & 1 \\
\hline Atlant & 28.4 & 28.9 & - & 31.1 & 31.1 & 40.0 & 31.9 & 1 \\
\hline Anait & 33.4 & 38.9 & 27.8 & - & 35.6 & 32.2 & 33.5 & 1 \\
\hline Narcicc & - & - & - & - & - & 36.7 & 36.7 & 1 \\
\hline Guarant & 38.9 & 33.3 & 34.4 & 41.1 & 38.6 & - & 37.2 & 2 \\
\hline Khazar & 26.2 & 35.6 & 31.1 & 53.3 & 31.1 & 50.0 & 37.8 & 2 \\
\hline Phlagman & 46.1 & 45.6 & 25.6 & 43.3 & 34.5 & 36.7 & 38.6 & 2 \\
\hline Jupiter & - & 38.9 & - & - & - & - & 38.9 & 2 \\
\hline Leader & 47.2 & 40.6 & 30.0 & 39.4 & - & - & 39.3 & 2 \\
\hline Jantar & 45 & 48.9 & 40.0 & 33.3 & 36.6 & - & 40.7 & 2 \\
\hline Regul & 45.6 & 45.6 & 34.4 & 50.2 & 32.4 & - & 41.6 & 2 \\
\hline Liman & 43.9 & 37.8 & - & 44.5 & 43.7 & - & 42.4 & 2 \\
\hline Izumryd & 55.6 & 37.8 & 42.2 & 47.8 & 47.8 & & 46.2 & 2 \\
\hline Rapan & 61.1 & 46.1 & 45.6 & 48.9 & 42.5 & 35.5 & 46.6 & 2 \\
\hline Serpentine & 38.9 & 58.9 & -- & - & - & - & 48.9 & 2 \\
\hline Kurchanka & 47.8 & 49.5 & 50.0 & 48.9 & 50.6 & - & 49.3 & 2 \\
\hline Khankaiskiy & - & - & 37.8 & 61.1 & - & - & 49.4 & 2 \\
\hline Charm & 48.4 & 52.2 & 64.4 & 30 & 62.2 & 50.1 & 51.2 & 3 \\
\hline Amethyst & - & - & 50.7 & 56.7 & 51.8 & - & 53.0 & 3 \\
\hline Novator & 52.2 & 46.7 & 53.3 & 65.6 & 53.3 & - & 54.2 & 3 \\
\hline Pavlovskiy & - & 55.6 & - & - & - & - & 55.6 & 3 \\
\hline Phontan & 60.1 & - & - & - & - & - & 60.1 & 3 \\
\hline Dalnevostochniy & - & - & - & - & - & 76.7 & 76.7 & 3 \\
\hline
\end{tabular}

To isolate DNA from rice seedlings and leaves, the STAB method with modifications was used. Polymerase chain reaction (PCR) and analysis of the obtained amplification product were carried out according to the methodology of the International Rice Institute [12]. The following PCR parameters were used in the experiment: initial denaturation for five minutes at $94{ }^{0} \mathrm{C}$, thirty-five cycles: $60 \mathrm{sec}$. - denaturation $94{ }^{\circ} \mathrm{C}, 60 \mathrm{sec}$. - annealing of primers at $55{ }^{\circ} \mathrm{C}, 120 \mathrm{sec}$ - synthesis of $72{ }^{0} \mathrm{C}$; elongation $-420 \mathrm{sec} .72{ }^{0} \mathrm{C}$. The volume of the PCR reaction is $10 \mu \mathrm{l}$ : DNA - $2 \mu \mathrm{l}), 1 \mu \mathrm{l}(1 \mathrm{~mm})$ of deoxynucleotide triphosphates; 3.7 $\mu \mathrm{l} \mathrm{H}_{2} \mathrm{O} ; 1 \mu \mathrm{l}$ of PCR buffer solution, $0.5 \mu \mathrm{l}$ of each primer, $1 \mu \mathrm{l}$ of Taq polymerase. Electrophoresis was carried out using a polyacrylamide gel at a voltage of $100 \mathrm{~V}$. Data processing was carried out in the Statistica 10 program; the group selection method was 
used for marking [13-14]. The studied markers were distributed across all 12 chromosomes of rice.

When dividing varieties into 2 groups, stable (group 1) and unstable (group 2 and 3), two loci were identified reliably with marker RM289 and RM5371 (Figure 1).
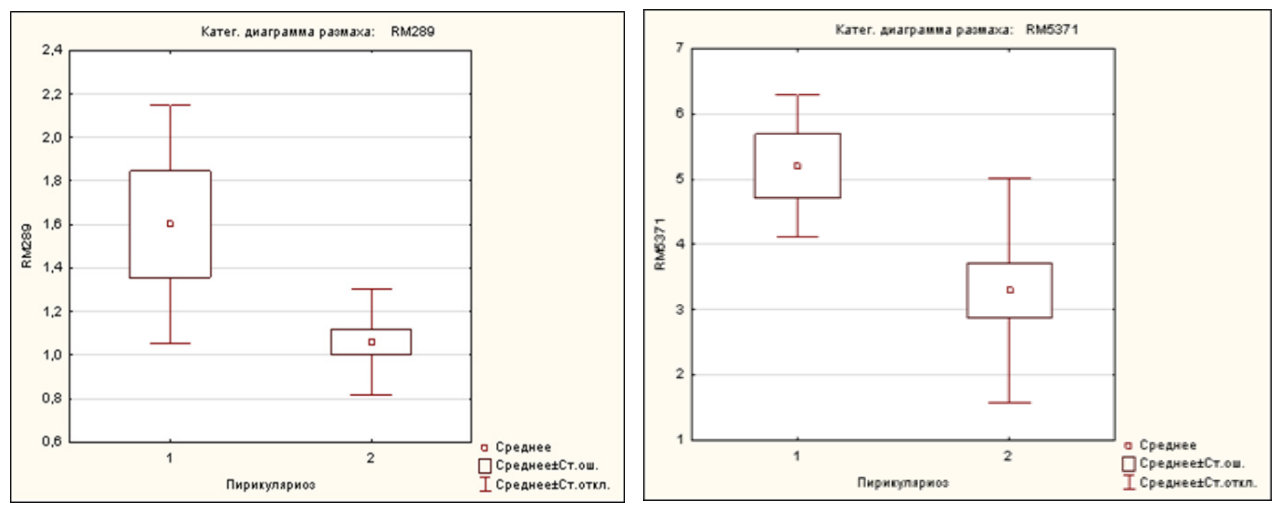

Fig. 1. Separation groups of Russian varieties with different resistance to blast using SSR molecular markers: a) RM289; b) RM5371

A decrease in the significance level to 0.09 increased the sensitivity of the method and made it possible to isolate another 5 loci with a possible arrangement of genes that determine stability (Table 2).

Table 2. SSR markers that reliably distinguish between groups of rice varieties contrasting in their resistance to blast

\begin{tabular}{|l|c|c|c|c|c|c|c|c|}
\hline SSR marker & $\begin{array}{c}\text { SS } \\
\text { Effect }^{*}\end{array}$ & df. $^{*}$ & $\begin{array}{c}\text { MS } \\
\text { Effect }^{*}\end{array}$ & $\begin{array}{c}\text { SS } \\
\text { Effect* }\end{array}$ & df. & $\begin{array}{c}\text { Cp. } \\
\text { квад. }\end{array}$ & F $^{*}$ & p $^{*}$ \\
\hline RM259 & 0.13690 & 1 & 0.13690 & 49.3176 & 20 & 2.46588 & 0.05552 & 0.816123 \\
\hline RM444 & 0.15455 & 1 & 0.15455 & 0.8000 & 20 & 0.04000 & 3.86364 & 0.063383 \\
\hline RM126 & 0.65508 & 1 & 0.65508 & 4.1176 & 20 & 0.20588 & 3.18182 & 0.089644 \\
\hline RM53 & 0.41925 & 1 & 0.41925 & 7.0353 & 20 & 0.35176 & 1.19185 & 0.287934 \\
\hline RM255 & 0.05348 & 1 & 0.05348 & 1.7647 & 20 & 0.08824 & 0.60606 & 0.445388 \\
\hline RM5361 & 1.73743 & 1 & 1.73743 & 11.0353 & 20 & 0.55176 & 3.14887 & 0.091204 \\
\hline RM5508 & 5.78396 & 1 & 5.78396 & 85.6706 & 20 & 4.28353 & 1.35028 & 0.258909 \\
\hline RM6024 & 0.15455 & 1 & 0.15455 & 0.8000 & 20 & 0.04000 & 3.86364 & 0.063383 \\
\hline RM2770 & 0.13690 & 1 & 0.13690 & 41.3176 & 20 & 2.06588 & 0.06627 & 0.799483 \\
\hline RM13 & 0.21390 & 1 & 0.21390 & 5.0588 & 20 & 0.25294 & 0.84567 & 0.368740 \\
\hline RM25 & 0.07701 & 1 & 0.07701 & 1.7412 & 20 & 0.08706 & 0.88452 & 0.358188 \\
\hline RM227 & 0.01337 & 1 & 0.01337 & 0.9412 & 20 & 0.04706 & 0.28409 & 0.599906 \\
\hline RM286 & 2.25936 & 1 & 2.25936 & 31.0588 & 20 & 1.55294 & 1.45489 & 0.241820 \\
\hline RM3428 & 0.02620 & 1 & 0.02620 & 4.5647 & 20 & 0.22824 & 0.11481 & 0.738267 \\
\hline RM5371 & 14.03422 & 1 & 14.03422 & 52.3294 & 20 & 2.61647 & 5.36380 & 0.031292 \\
\hline RM7187 & 0.00000 & 1 & 0.00000 & 0.0000 & 20 & 0.00000 & & \\
\hline RM6314 & 0.19305 & 1 & 0.19305 & 5.6706 & 20 & 0.28353 & 0.68088 & 0.419019 \\
\hline RM6811 & 2.84973 & 1 & 2.84973 & 17.7412 & 20 & 0.88706 & 3.21256 & 0.088216 \\
\hline RM5638 & 0.00053 & 1 & 0.00053 & 19.3176 & 20 & 0.96588 & 0.00055 & 0.981461 \\
\hline RM5707 & 0.48128 & 1 & 0.48128 & 23.8824 & 20 & 1.19412 & 0.40305 & 0.532717 \\
\hline RM8243 & 0.00000 & 1 & 0.00000 & 0.0000 & 20 & 0.00000 & & \\
\hline RM6410 & 0.10481 & 1 & 0.10481 & 4.2588 & 20 & 0.21294 & 0.49221 & 0.491025 \\
\hline
\end{tabular}




\begin{tabular}{|l|c|c|c|c|c|c|c|c|}
\hline RM463 & 0.08571 & 1 & 0.08571 & 8.2000 & 20 & 0.43158 & 0.19861 & 0.660885 \\
\hline RM289 & 1.13155 & 1 & 1.13155 & 2.1412 & 20 & 0.10706 & 10.56943 & 0.004001 \\
\hline
\end{tabular}
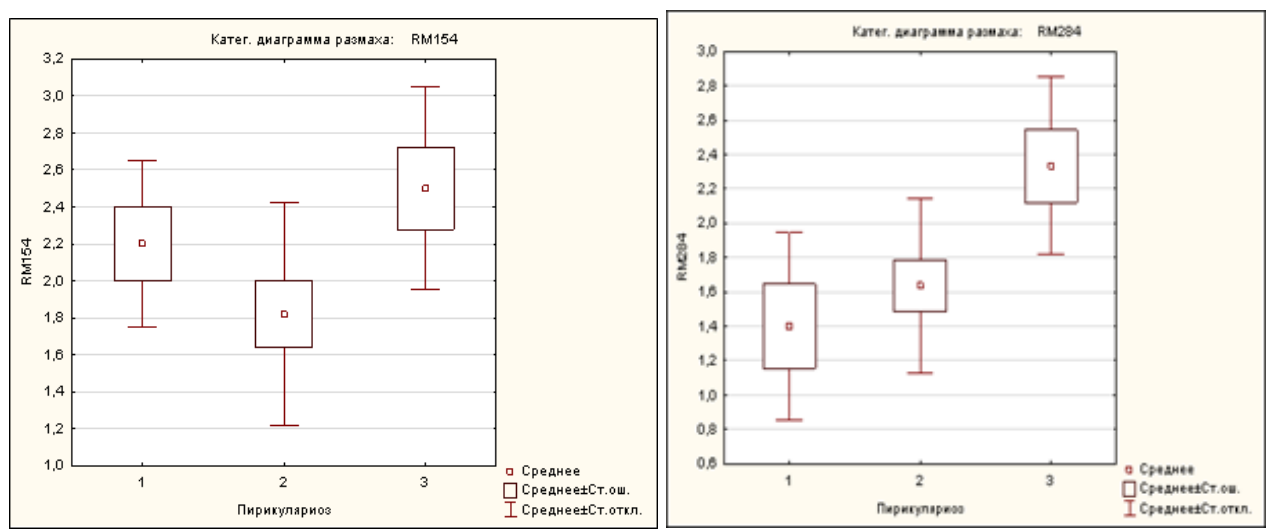

Fig. 2. Separation of groups of Russian varieties with different resistance to blast using SSR molecular markers: a) RM154; b) RM284

The division of varieties into 3 groups allowed us to isolate the locus on the eighth chromosome near marker RM284 (Figure 2, table 3). A decrease in the significance level (to 0.09 ) increased the sensitivity threshold of the method and revealed another locus with a possible effect on the formation of the trait.

Table 3. SSR markers that reliably distinguish groups of rice varieties contrasting in their resistance to blast

\begin{tabular}{|l|l|l|}
\hline \multirow{2}{*}{ Variety Groups } & \multicolumn{2}{|c|}{ SSR marker (chromosome); chromosome locus } \\
\cline { 2 - 3 } & \multicolumn{1}{|c|}{ Significance Level 0.05 } & \multicolumn{1}{c|}{ Significance Level 0.09 } \\
\hline Two groups of & RM 289(5); 36,2cM & RM 126(6); 57cM \\
varieties & RM 5371(6); 25,8 cM & RM 5361(5); 6,3cM \\
& & RM 444(9);3,3 cM \\
& & RM 6811(6); 115,6 cM \\
& & RM 6024(5); 17,7cM \\
\hline Three groups of & RM 284(8);104,3cM & RM 154 (2); 4,8cM \\
varieties & & RM 289(5);36 cM \\
\hline
\end{tabular}

The data obtained are consistent with the results of previous studies in this area [16]. According to the literature [15-16], many genes for resistance to blast are localized in the chromosomal regions that we have identified (Figure 3). 


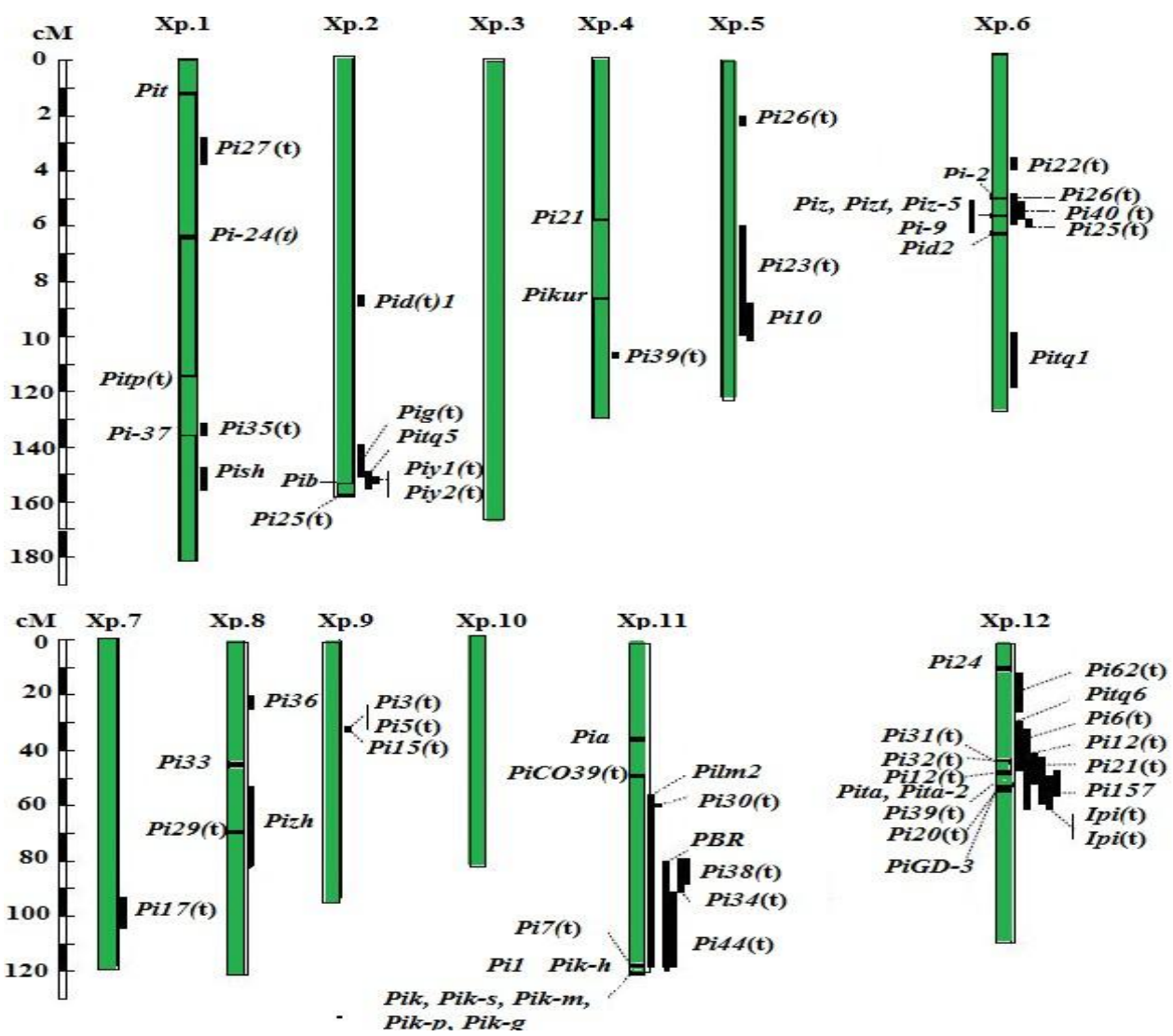

Fig. 3. Map of the distribution of genes for resistance to blast (O.sativa) http://www.jircas.affrc.go.jp [15]

So on the sixth chromosome there is a large cluster of resistance genes, which includes eleven genes (Pi-2, Piz, Pizt, Piz-5, Pi-9, Pid2, Pi22 (t), Pi26 (t), Pi40 (t) Pi25 (t), Pitq1). On the fifth chromosome, in the region where the marker RM 289 is located, the Pi26 ( $\mathrm{t}$ ) gene is located, and the markers RM 5361 and RM 6024 contain the Pi23 (t) and Pi10 loci. On the eighth chromosome in the marker region, polymorphism, which allowed us to reliably distinguish groups of samples with contrast resistance to blast, contains the genes Pi26, Pi33, Pi29 (t). Clusters of five to seven resistance genes were also detected on the second and ninth chromosomes.

Therefore, in order to reduce the laboriousness of evaluating breeding material when identifying sources of vertical resistance, the variability of $\mathrm{Pi}$ genes in the identified chromosomal regions should be studied first. On the ninth chromosome, the stability of the studied samples can be due to the presence of the genes Pi-3 (t), Pi5, Piii, Pi28 (t), Pi15 (t). The locus Pi-d (t) 1 is located closest to the second, but it is also possible to determine the trait due to the operation of the cluster, which includes the genes: Pi-g (t), Pitq5, Piyl ( $\mathrm{t}$ ), Piy2 (t), Pib.

This work was supported by the Russian Science Foundation No. 19-16-00064, the Russian Federal Property Fund and the Administration of the Krasnodar Territory No. 19416-233009 


\section{References}

1. A. Khanna,V. Sharma,K. Ranjith, A.Shikariet al. Theoretical and applied genetics, 128, 1243-1259, (2015) https://doi.org/10.1007/s00122-015-2502-4

2. S. Ashkani, M.Y. Rafii, H.A. Rahim and M.A. Latif. Mol. Biol. Rep. 40, $2503-$ 2515. (2013) https://doi.org/10.1007/s11033-012-2331-3

3. M. Yadav, S. Aravindan, U. Ngangkham, S. Raghu, S. Prabhukarthikeyan, U. Keerthana et al., Genetic dissection by gene specific markers. PLOS ONE 14(3), (2019) https://doi.org/10.1371/journal.pone.0213566

4. X. Wu-ming, L. Li-xin, W. Hui1, G. Tao, L. Yong-zhu, Z. Ji-yong, Z. Xiao-yuan, Y. Qi-yun, C. Zhi-qiang Journal of Integrative Agriculture 15(10), 2290-2298, (2016) https://doi.org/10.1016/S2095-3119(16)61415-6

5. X. Zhang, S. Yang, J. Wang, Y.Jia1, J. Huang, S. Tan1, Y.Zhong, L. Wang, L. Gu1, J. Chen, Q. Pan, J. Bergelson, and D. Tian1,Plant J. 84(1), 20-28, (2015) https://doi.org/10.1111/tpj.12955

6. W. Xiao, Q. Yang, M. Huang, T. Guo, Y. Liu, J. Wang, G. Yang, J. Zhou, J. Yang, X. Zhu, Z. Chen, and H. Rice 12, 78, (2019)

7. W. Luo, M. Huang, T. Guo, W. Xiao, J. Wang, et al. Plant Breed 136, 67-73(2017)

8. S.H. Basavaraj, V.K. Singh, A. Singh, A. Singh, et al. Mol. Breed. 26, 293-305 (2010). doi. org/10.1007/s11032-010-9407-3

9. S. Ashkani, M.Y. Rafii, M. Shabanimofrad, G. Miah, et al. Front. Plant Sci. 6, 886. (2015) https://doi.org/10.3389/fpls.2015.00886

10. H. Huang, L. Huang, G. Feng, S. Wang, Y. Wang, J. Liu, N. Jiang, W. Yan, L. Xu, P. Sun, Z. Li, S Pan., X. Liu, et al. European Journal of Plant Pathology, 148, 955-965 (2017)

11. H. Jiang, Y. Feng, L. Bao, X. Li, G. Gao, Q. Zhang, J. Xiao, C. Xu, Y. He, Molecular Breeding, 30, 1679-1688, (2012)

12. J. Jiang, D. Yang, J. Ali,T. Mou Molecular Breeding, 101, 620-626, (2015)

13. V.V. Tyurin, S.N. Shcheglov Discriminant analysis in biology (2015)

14. J.K. Goncharova, S.V. Gontcharov, E.E. Chicharova Russian Journal of Genetics, 54, 7,796-804, (2018) https://doi.org/10.1134/S1022795418070037

15. Y. Koide, N. Kobayashi, D. Xu, Y. Fukuta, JARQ 43(4), 255-280 (2009) http://www.jircas.affrc.go.jp

16. X. Wang, J. Lee, J. Wang, T. Bianco, and Y. Jia Rice - Germplasm, Genetics and Improvement. 195-217 (2014) https://www.researchgate.net/publication/292382245 